\title{
Problems and Conditions of Sustainable Economic Development of the Russian Timber Industry Complex
}

\author{
Yulia Romanova \\ Institute of Market Problems \\ Financial University under the Government of the Russian \\ Federation \\ Moscow, Russia \\ Ryulia1@yandex.ru
}

\author{
Anna Egorenko \\ Management Department \\ Financial University under the Government of the Russian \\ Federation \\ Moscow, Russia \\ annaegorenko@yandex.ru
}

\begin{abstract}
The article is devoted to the issues of formation and economic development of the national timber industry complex. The article defines the main conditions for sustainable economic growth based on the principles of management in the timber complex. The main attention is paid to the direct state administration that operates in the framework of state property, as well as to improving economic management, which should take the direction of creating integrated structures based on the principles of public-private partnership. Therefore, the problems and conditions for sustainable economic growth and development of the timber industry complex are extremely topical and insufficiently developed in the scientific literature.
\end{abstract}

Keywords—economic development; timber industry complex; business segments

\section{INTRODUCTION}

The timber complex plays a strategic role for economic development both in individual regions and throughout Russia. In this regard, there is a growing interest in developing alternative methods (both theoretical and practical) of managing entrepreneurial relations in the industry that ensure competitiveness, investment attractiveness and economic growth of its subjects.

The search for innovative forms of management in the timber complex is conditioned by the choice of principles of rational and sustainable forest industry management aimed at maintaining the natural-ecological and economic balance, increasing the efficiency of the functioning of business entities in the industry, and satisfying consumers with forest resources.

The functioning of the timber complex in Russia at the present time is connected with a multitude of systemic problems, complicated by the prevailing economic situation in the country. The propagandized principle of sustainable forest management is rather formal and not coordinated with land management, which requires improving the institutional environment of the timber complex, taking into account the interests of all the parties involved: the state, business communities, and consumers.

The following Russian authors covered the issues of formation and economic development of the timber industry complex as a whole in their work: Khashib B.O., Erznkian B.A., Arutyunyan S.M., Medvedeva O.S., Zakharov P.V Lysych M.N., Chernyshev A.V., Pinyagina N.B., Gorshenina N.S., Nazarenko E.B., Gamsakhurdia O.V., Starikov E.N., Gnezdova Y.V. and others.

The solution of these problems is the introduction of an enterprise management system in the Russian timber complex which should be focused on intensification of activities.

Intensification in the timber complex contributes not only to the development of business and getting a significant profit, but also to the regulation of the social and economic problems of the industry, which ultimately ensures the sustainable development of the economic entity itself.

\section{FORMATION AND FUNCTIONING OF TIMBER} INDUSTRY ENTERPRISES IN THE RUSSIAN FEDERATION

The Russian timber complex has a high potential whose development requires the transition to the intensive management model and the formation of sustainable forest management.

Taking into account the peculiarities of the forest complex, it is advisable to consider the management system in the form of activities coordinating the distribution of limited resources of the forestry economy as a natural and economic system [1]. Management of the natural and economic system requires a combination of principles of general management theory and state regulation of the market economy "Fig. 1". 


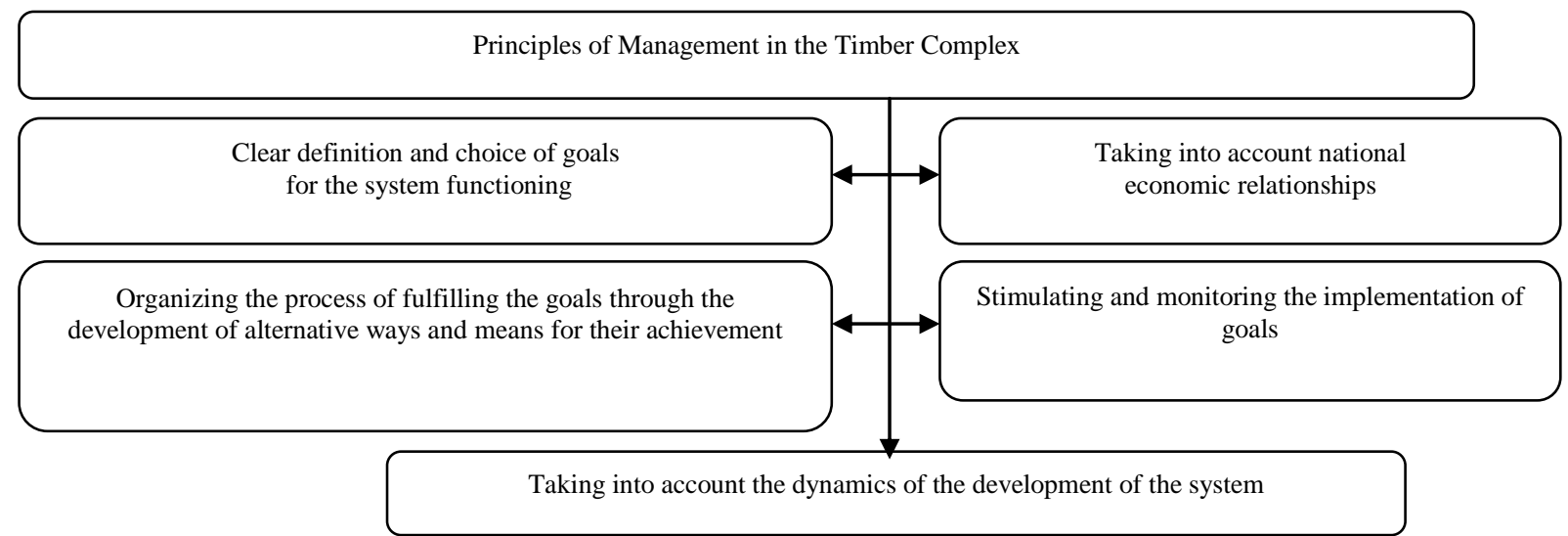

Fig. 1. Principles of management in the timber complex of Russia.

In the timber complex economic management should be interpreted as the interaction between a managed object and a management entity aimed at organizing production management in forestry, secondary processing, selling timber products and raw materials, servicing forestry facilities, realizing specific functions conditioned by socioeconomic and industrial relationships in the timber complex.

The state, being the main owner of the forest, is responsible for preserving resources. The main drawback of the state timber management of Russia is high centralization, which hinders effective interaction between state authorities and entrepreneurs [2].

The timber complex appears to be a polycentric system, which complicates the management system in it, as there are many target parameters and many control centers, which ultimately determines the final effectiveness of the management process.

\section{SYSTEMIC PROBLEMS, CONDITIONS FOR} SUSTAINABLE DEVELOPMENT AND THE FORMATION OF A MODEL OF BUSINESS SEGMENTS IN THE RUSSIAN TIMBER

\section{COMPLEX}

The economy of the timber complex determines the level of socio-economic development of half of the subjects of the Russian Federation, where the area of forest fund lands occupies up to $80 \%$ of the entire territory. In this regard, the tasks of developing methods for using various forms of public-private partnership in forest development are being actualized [3].

The forests of Russia constitute 1.18 billion hectares. The total wood stock value is 82.1 billion $\mathrm{m} 3$, which is $25 \%$ of the total world level, and 4 times more than in the US, 3.7 times more than in Canada. The annual allowable volume of timber withdrawal in Russia is 635 million $\mathrm{m} 3$, while the actual harvest is about $30 \%$.

The size of Russia's forest resources is so significant that it allows us to cover the needs of both domestic and foreign markets with high-quality timber and its derivative products.

The volume of forest resources that the Russian Federation possesses is able to provide not only the current but also the long-term needs of the country, the potential for expanding timber and derivative products exports is very significant [4].

Forest areas are a large part of the country's territory, however, the share of the timber industry in GDP is only $1.3 \%$; the volume of industrial output is $3.7 \%$, and the export currency earnings of the country is $2.4 \%$. The listed facts are the evidence of using the forest potential of the country insufficiently. Characterizing the systemic problems in the timber industry complex, we can note the following "Fig. 2".

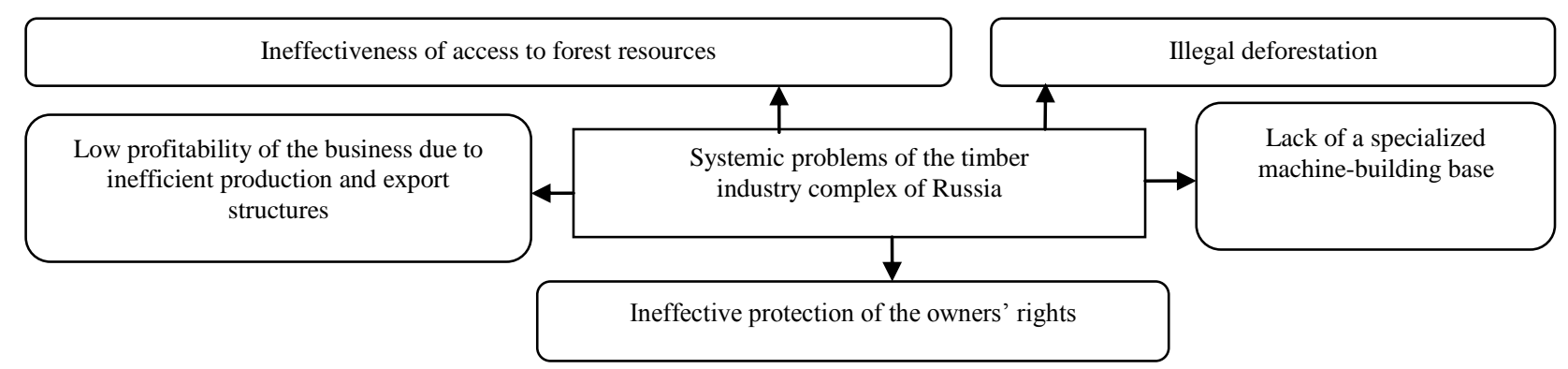

Fig. 2. Systemic problems of the timber industry complex in Russia.

According to the Federal State Statistics Service, in 2013-2016 the pace of economic development of the timber industry of the Russian Federation decreased compared to the previous years. Negative dynamics is observed in the 
logging sector. Pulp and paper production in the reporting year is characterized by a reduction in output for almost all types of products, with the exception of container board. The value of the woodworking industry index in 2013 was $101.4 \%$. The index of the logging industry by 2012 amounted to $97.2 \%$. The indicators of the forestry sector development are weakened by the low profitability of the pulp and paper sector.

The economic potential of the Russian forestry complex remains unrealized. Its contribution to the country's GDP is constantly declining, despite the obvious opportunities for increasing the incomes of both the state and business entities of the forest complex. Currently, neither government bodies, nor business entities or business structures can effectively manage forest resources [5].

At first sight, the revealed systemic problems testify to the stagnation and reduction of growth reserves in the Russian timber complex, at the same time, the analysis of the existing potential of the forestry complex makes it possible to identify the conditions conducive to the sustainable development of the industry in the long-term prospects "Fig. $3 "$.

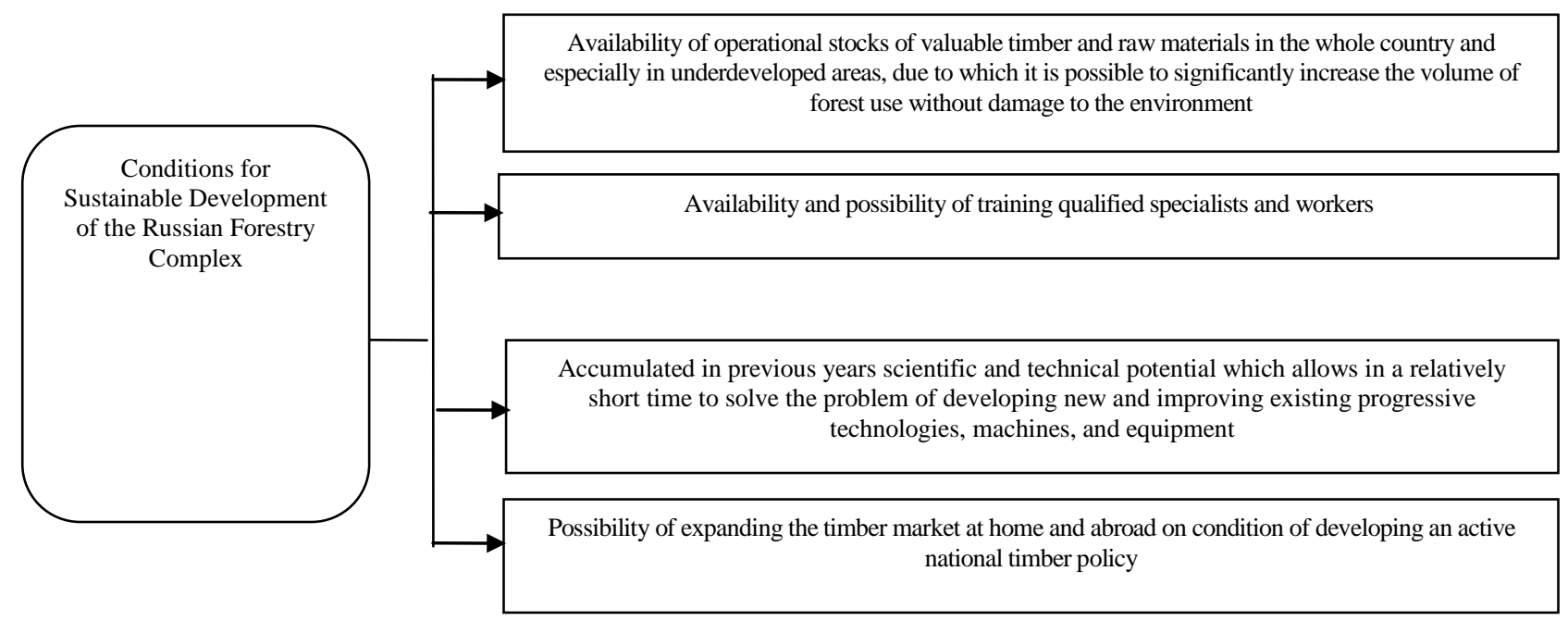

Fig. 3. Conditions for Sustainable Development of the Russian Forestry Complex.

The development process is associated with the emergence of such contradictory problems as growing needs and limiting the capacity of natural resources needed to meet these needs, as well as the interconnection and interdependence of the state of the environment and the potential increase in the results of entrepreneurial activities of economic entities. High business growth rates should be accompanied by the implementation of a policy of rational nature management, otherwise an ecological catastrophe is inevitable. Pollution of the environment and depletion of natural resources will ultimately lead to a decrease in national income [6].

The basis of the timber complex management in Russia should be the integrity of the system with the inclusion of the state and various forms of entrepreneurship in it as a guarantor of economic growth of the industry. In this context the use of the model of rational entrepreneurial-oriented management in the timber complex should be regarded as a systematic, purposeful influence of society on the forest complex as a whole or on its elements, taking into account objective laws and trends in the interests of optimal development of both the industry and the economy as a whole [7].

The most important strategic goal is to optimize the location and structure of forest resources in accordance with the characteristics of the territory on the basis of the choice of systems for the use and reproduction of forest resources, types, forms and structures of forest entrepreneurship.

Over the past few years there has been a significant contradiction in the timber complex with the need for clear management and the actual situation in this area. On the one hand, there are reorganization changes in the central environmental management bodies, on the other hand, there is apparent inconsistency of actions and the disorientation of local authorities in the industry. The reasonableness of forest payments is doubtful, the effective mechanism of their return to the forest complex has not been worked out. This becomes most apparent in the crisis period, when the interests of the state are shifted to the area of anti-crisis measures, while the timber complex is not assessed as strategically important for stabilizing the economic situation in the country [8].

Analyzing domestic and foreign practice, one can come to the conclusion that it is necessary to solve the environmental problem at all levels. The investment process materializes the decisions made equally productively in various spheres, ranging from business to the protection of the natural environment, including the forestry sphere. Investment activity in the timber complex is included in the overall investment environment and is limited by the opportunities of the state and those of private business on the other hand [9]. 
The degree of investment attractiveness of the forestry sector increases with the participation of the state, thereby increasing the importance of creating public-private partnerships in the Russian forestry complex. In the context of the economic crisis the issue of the management strategy of the forest complex becomes very acute and topical. This strategy must provide not only flexible adaptation to changes in the external and internal environment, but also should contribute to the formation of new entrepreneurial-oriented models of development [10].

The state of small "forest" entrepreneurship on the territory of the country can be described as follows: the significance of this industry in Russia's GDP for 2016 is slightly more than $1 \%$, in currency revenues - about $2 \%$, in the volume of world trade - about $3 \%$. However, according to Russian experts, there is a real opportunity to increase several times the state's revenues from the forest sector and the employment of the population, as well as the development of small forest industry enterprises.

The level of innovative activity of small forest enterprises is estimated as the share of high technologies in the total volume of products and the number of patents. Thus, the share of science-intensive technologies in the total volume of forest products in the country has quite low values in comparison with the expenditures of the federal budget for innovative activity in the civil sector [11].

The management of modern small business in the country's forestry complex is, above all, the management of a certain set of business areas in order to obtain synergistic effects in the gross domestic product. Business in the timber complex consists of a variety of activities that can be divided into several main types "Table I".

TABLE I. Business SEgMENTS OF THE RUSSIAN TIMBER COMPLEX

\begin{tabular}{|l|l|l|}
\hline I. Materials segment & $\begin{array}{l}\text { II. Semi-finished } \\
\text { products segment }\end{array}$ & $\begin{array}{l}\text { III. Advanced } \\
\text { processing } \\
\text { products segment }\end{array}$ \\
\hline $\begin{array}{l}\text { raw materials } \\
\text { (balancers, industrial } \\
\text { wood, chipped } \\
\text { wood) }\end{array}$ & $\begin{array}{l}\text { chemical processing } \\
\text { (cellulose, } \\
\text { dendrochemistry } \\
\text { products) }\end{array}$ & packing \\
\hline $\begin{array}{l}\text { processed raw } \\
\text { materials (scrap } \\
\text { paper) }\end{array}$ & $\begin{array}{l}\text { mechanical processing } \\
\text { (panels, ply wood, } \\
\text { lumber) }\end{array}$ & paper and cardboard \\
\hline & canvas & $\begin{array}{l}\text { sanitary and hygienic } \\
\text { products }\end{array}$ \\
\hline & & furniture blanks \\
\hline
\end{tabular}

The level of the number of small timber enterprises and the level of the gross domestic product are two interdependent inversely proportional indicators. Thus, the dynamics of the change of the former indicator (factor) will also influence economic development as a whole. As follows from the presented model, the greatest positive impact on the effectiveness of innovative activities of enterprises of the forestry complex of the country is provided by the acquisition of new equipment, as well as training the staff.

\section{CONCLUSION}

The destruction of the forest management system has led to a sharp decline in the management organization at the regional level. This is observed in various methodological approaches to the formation of management structures, which leads to the emergence of unorganized management systems that are unable to resolve and overcome the contradictions that are growing in the production, economic, financial and social activities of economic entities. The improvement of economic management should take the direction of creating integrated structures based on the principles of public-private partnership.

At present the required conditions for attracting investments to any sector of the economy, in particular to the timber industry complex, are as follows: a developed social infrastructure, a competent social apparatus, a stable macroeconomic situation, and a stable political system.

\section{REFERENCES}

[1] M. A. Muravieva, O.G. Nazarova, V.V. Silaeva, Innovative direction of the regional timber sector development. Monograph. Moscow, World of Science Publishing House.

[2] N. B. Piniagina, N.S. Gorshenina, E.B. Nazarenko, O.V. Gamsakhurdia, Trends and prospects for the development of the Russian timber sector // Forest Messenger. Forestry Bulletin, Bauman Moscow State Technical University Press, Moscow, Vol. 20, No. 2 , 2016.

[3] Y. V. Gnezdova, Analytical review of the application of energy conservation policies in Russia, Raleigh-North Carolina, 2016, p. 256.

[4] P. V. Zakharov, M.N. Lysych, A.V. Chernyshev, Problems of the Russian timber complex and ways of their solution // Actual directions of scientific research of the 21st century: theory and practice. Morozov Voronezh State Forestry University, Voronezh, No. 9-3 (20-3), 2015.

[5] E. N. Starikov, Industrial policy: approaches to the formation and management of sales. Monograph, Ural State Forestry University Press, Yekaterinburg, 2017.

[6] B. A. Erznkian, S. M. Arutyunyan, Timber industry complex of Russia: financing problems and modernization prospects. Economic analysis: theory and practice. Finansy i Kredity Publishing House, No. 4 (463), 2017.

[7] N. G. Tyukalova, E.A. Svetlaya, Timber industry in Russia and in the Perm region. The proceedings of the conference Strategy of sustainable development of regions: A new view. Collection of the scientific papers on the materials of the I International Scientific and Practical Conference. Professional Science, 2016.

[8] O. S. Medvedeva, Timber Industry Cluster as a New Brand of the Region: Formation Conditions and Management Practices. Scientific Works of the Free Economic Society of Russia, Free Economic Society of Russia, Vol. 198, M.: 2016.

[9] B. O. Khashib, Trends and directions of development of the regional forest complex. Actual problems of the forest complex, Bryansk State Engineering and Technological Academy Press, No. 45, 2016.

[10] A. Savitsky, N.S. Gorshenina, O.V. Gamsakhurdia, E.B. Nazarenko, Actual issues of assessing the investment climate of the Russian timber sector // Economics and Entrepreneurship, Editorial Board of the Economy and Entrepreneurship, No. 4-2 (69-2), 2016.

[11] N. Osipov, Y.V. Gnezdova, D.V. Kuzin, I.M. Rukina, G.N. Tsagalov, Public-private partnership as a model for the development of the country's innovative economy, The Economics of Agriculture in Russia, No. 1, 2016, pp. 26-33. 